\title{
Relationship between anthocyanins and skin color of table grapes treated with abscisic acid at different stages of berry ripening
}

\author{
Muhammad Shahab $^{\text {a }}$, Sergio Ruffo Roberto ${ }^{\mathrm{a}, *}$, Saeed Ahmed ${ }^{\mathrm{a}}$, Ronan Carlos Colombo ${ }^{\mathrm{a}}$, \\ João Pedro Silvestre ${ }^{\mathrm{a}}$, Renata Koyama ${ }^{\mathrm{a}}$, Reginaldo Teodoro de Souza ${ }^{\mathrm{b}}$ \\ ${ }^{a}$ Agricultural Research Center, Londrina State University, Celso Garcia Cid Road, km 380, P.O. Box 10.011, 86057-970, Londrina, PR, Brazil \\ ${ }^{\mathrm{b}}$ Embrapa Grape and Wine, P.O. Box 130, 95700-00 Bento Gonçalves, RS, Brazil
}

\section{A R T I C L E I N F O}

\section{Keywords:}

Vitis vinifera $\mathrm{L}$.

Grapevines

Plant growth regulators

(S)-cis-abscisic acid

Quality attributes

\begin{abstract}
A B S T R A C T
Grapes grown under warm climate conditions tend to show less color development, and this phenomenon is attributed to low anthocyanin accumulation in berry skin in response to high temperature during ripening. 'Benitaka' (Vitis vinifera L.) is a table grape that shows poor color development when grown under a subtropical condition, and the exogenous application of $(S)$-cis-abscisic acid ( $S$-ABA) is a recently developed technique used to overcome this difficulty. Trials were conducted during two crop seasons in a commercial vineyard containing 11-year-old 'Benitaka' vines grafted onto 'IAC 766 Campinas' rootstocks in Marialva, State of Parana (PR), Brazil. The vines were trained on an overhead trellis system, covered with a black plastic mash, and spaced $3.0 \times 6.0 \mathrm{~m}$ apart. A randomized block design was used and treatments included the application of $400 \mathrm{mg} \mathrm{L}^{-1}$ of $S$-ABA at different stages of ripening, as follows: Control (no application); At pre-veraison (PRV) (7 days before veraison); At veraison (V); and At post-veraison (POV) (7 days after V). A second application was performed for all treatments, 10 days after the first application, except for the control. The analysis of berries included, total and daily anthocyanins accumulation, the color index of red grapes (CIRG), daily CIRG development, lightness ( $L^{*}$ ), chroma $\left(C^{*}\right)$, hue angle $\left(h^{\circ}\right)$, mass, length, width, firmness, total soluble solids (TSS), titratable acidy (TA), the index of maturation (TSS/TA), and total polyphenols of berries. The exogenous application of $S$-ABA from PRV to POV significantly enhanced the contents and rates of total anthocyanins accumulation and the CIRG of 'Benitaka' table grape; however, the application at PRV and V provided a higher response. A stronger correlation exists between anthocyanin concentration and the color index of berry skin, however, the main physicochemical characteristics of berries are not significantly affected by the use of $S$-ABA. Berry firmness varies in response to $S$ ABA application, but not to an extent at which it compromises berry quality for commercial use.
\end{abstract}

\section{Introduction}

Over the last years, the growing area of 'Benitaka' table grape (Vitis vinifera L.) has increased in several subtropical regions due to its exceptional features (Kishino et al., 2019). It is an important colored cultivar, which originated from the somatic mutation of the 'Italia' table grape (Leão et al., 2009), however, the lack of a pink and uniform color of berry skins is frequently observed when this cultivar is grown under a warm climate (Roberto et al., 2012).

The appearance of grapes highly influences their commercial value, and the red/pink cultivars with poor coloration result in low consumer acceptance (Peppi et al., 2006). Further, the color of grapes is directly influenced by the amount and composition of anthocyanins present in their skin. Anthocyanins are responsible for blue, purple, and all tones of red color of fruits, vegetables, and flowers (Ban et al., 2003; Owen et al., 2009). Flavonols and phenolic acids, known as polyphenols, act as co-pigments to stabilize this color. These are important secondary metabolites present in the different parts of grapes (Chira et al., 2011; Flamini et al., 2013).

The accumulation of anthocyanins starts at the time of veraison, which is considered as the onset of the ripening of berries (Castellarin et al., 2007a, b; Lecourieux et al., 2014). Veraison of grapes is typically 7-10 days long, or even more, signaling a shift from a photosynthetic to a heterotrophic metabolism (Keller, 2015), and can be identified from an increase in soluble solids content, berry softening, and a sudden increase in the skin color (Huang and Huang, 2001).

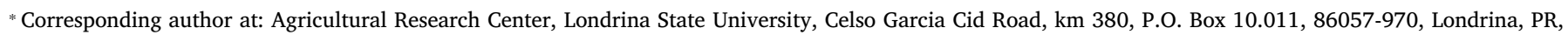
Brazil.

E-mail address: sroberto@uel.br (S.R. Roberto).
} 
This phenological stage can be divided into three distinct phases: pre-veraison, veraison, and post-veraison. The timing and lengths of these phases may vary among different cultivars growing in different climates. The time period between the start of fruit set and the beginning of veraison can be regarded as the pre-veraison phase; the preveraison phase can stretch up to 59 days from the start of the fruit set (Zamboni et al., 2010). Within a few days from the start of veraison, berries start to grow dramatically due to the accumulation of fructose and glucose; during this period the acids in the berries decline. All these characteristics are associated with engustment, when sugar accumulation starts to soften the berries (Robinson, 2006). Although there is no specific time frame for the post-veraison stage, it may be explained as the time period from the end of veraison until the start of harvest; the ripening process starts between 98 to 112 days after the fruit set, depending on the cultivar (Zamboni et al., 2010).

Anthocyanins increase in the skin of grape berries through a variety of environmental stimuli, such as developmental signals, environmental stresses (light, temperature, irrigation, etc.), and plant growth regulators (Boss and Davies, 2009). It is a well-established fact that abscisic acid (ABA) naturally accumulates in grape skins at the onset of ripening, a period when the concentration of anthocyanins and other phenolic compounds also increase. ABA stimulates the buildup of DNA coding for several enzymes responsible for anthocyanin accumulation in grapes, including the UFGT gene (Jeong et al., 2004), which is responsible for anthocyanin biosynthesis in grape berries (Boss et al., 1996a, b; Kobayashi et al., 2002). Although this gene is present among all type of grapes, it is expressed only in red colored cultivars (Boss et al., 1996b).

Several studies have demonstrated the multiple applications of exogenous enantiomer $(S)$-cis-abscisic acid ( $S$-ABA) can increase the anthocyanin concentration in grape skin efficiently (Roberto et al., 2012, 2013; Koyama et al., 2014, 2019; Yamamoto et al., 2015; Domingues Neto et al., 2017). However, the application time and concentration of $S$-ABA are critically important for the effective improvement of color development in grape skin (Peppi et al., 2006, 2007a, 2008a); this may vary depending on the cultivar and area of application.

Applying S-ABA at the right time of veraison to improve the grapeskin color is not an easy task, especially for vines grown in subtropical areas, where the weather conditions are inconsistent, affecting the ripening of grapes. In addition, main changes in berry development at the veraison, such as sugar accumulation, color, and berry softening, also rely on each grape cultivar. Thus, it is very important to identify the exact timing of the veraison for 'Benitaka' table grape and to evaluate the $S$-ABA efficiency over a wider period of time to improve berry color.

The objective of this study was, thus, to evaluate the relationship between anthocyanins and the skin color of 'Benitaka' table grapes grown in subtropical areas and treated with $S$-ABA at the different stages of the ripening of its berries.

\section{Material and methods}

\subsection{Grapevines and growing conditions}

The experiment was conducted in a commercial vineyard of 'Benitaka' table grape (Vitis vinifera L.) grafted onto 'IAC 766 Campinas' from 11-year-old vines in Marialva, State of Paraná (PR), Brazil $\left(23^{\circ} 29^{\prime} 52,8^{\prime \prime} \mathrm{S}, 51^{\circ} 47^{\prime} 58^{\prime \prime} 0 \mathrm{~W}\right.$, elevation $\left.570 \mathrm{~m}\right)$. The vineyard was grown under a double cropping system per year, during two consecutive seasons, 2015 and 2016 (summer and off-season crops, respectively). The vines were trained on an overhead trellis system, which were covered with a black plastic mesh, $3.0 \times 6.0 \mathrm{~m}$ apart. According to the Köppen classification, the climate of the area is type Cfa, i.e., subtropical with an average temperature below $18^{\circ} \mathrm{C}$ in winter and average temperature above $22^{\circ} \mathrm{C}$ in summer. The average annual rainfall in the area is $1596 \mathrm{~mm}$, with the most rainfall in summer
(IAPAR, 2010). In both seasons, vines were cane-pruned with 7-8 buds per cane, and $2.5 \%$ hydrogen cyanamide was applied to two terminal buds for budburst. During the trials, the standard regional cultivation practices with regard to nutrition, weed control, and pest and disease management were used (Roberto et al., 2012).

\subsection{Treatments and experimental design}

The treatments included the exogenous application of $400 \mathrm{mg} . \mathrm{L}^{-1}$ of $S$-ABA, as described by Roberto et al. (2012, 2013). The $S$-ABA containing 100 g.L $\mathrm{L}^{-1}$ of active ingredient was provided by Valent BioScienses ${ }^{\circledast}$ Corporation (Illinois, USA).

The following S-ABA treatments, applied on different timings of ripening (veraison) were tested: Control (no application); At pre-veraison (PRV) (at 7 days before veraison); At veraison (V); and At postveraison (POV) (at 7 days after V). A second application was performed for all treatments, 10 days after the first application, except for the control.

For the application of the treatments, a knapsack sprayer at a pressure of 568.93 psi (39.22 bar) was used, and the solution was applied onto the grape bunches exclusively until run-off, avoiding drifting to the leaves. In addition, a non-ionic surfactant BreakThru ${ }^{\circledast} 0.3 \mathrm{~mL} . \mathrm{L}^{-1}$ (Evonik Industries, Germany) was added to the solution.

To identify the exact timing in which the PRV phase began, samples of 30 berries were collected three times per week from the experimental vineyard, starting 40 days after flowering, and once a week at 80 days after flowering up to ripening. The berry samples were evaluated considering the total soluble solids content (TSS, ${ }^{\circ}$ Brix), firmness (N), and color index of red grapes (CIRG), which suddenly change at this phenological stage (Keller, 2015). The detailed methodology used is described ahead. In addition, 'Benitaka' vines near the experimental area, which were pruned earlier at different timings, were also closely observed to determine the number of days it took to reach veraison. At the beginning of the evaluation, the TSS contents were approximately $4^{\circ}$ Brix.

The first change observed was a slight increase in the TSS contents to $5.7^{\circ}$ Brix at 62 days after flowering (Fig. 1). However, other variables remained the same, i.e., the color of the berries did not change and were still as hard as recorded earlier. Based on these data and observations of the nearby vines that were pruned earlier, it was confirmed that it would take at least a week to reach a proper $\mathrm{V}$ phase. Hence, this timing was considered as PRV. As expected, these berries showed the signs of change exactly 7 days after PRV, and this was considered as $\mathrm{V}$, where at least $50 \%$ of the berries showed a slight variation in the color, firmness, and TSS of the berries.

A randomized block design was used as a statistical model with four treatments and five replications. Each plot consisted of a single vine, wherein ten grape bunches were marked for further analysis.

\subsection{Berry sampling and fruits analysis}

For both seasons, berries were harvested when the TSS stabilized around $14^{\circ} \mathrm{Brix}$, but not lower than $13^{\circ} \mathrm{Brix}$. Further, for evaluation, 30 berries were selected from the 10 marked bunches, 3 from each bunch (from top, middle, and bottom). The samples were split into three subsamples ( $\mathrm{n}=10$ berries) for total anthocyanins and polyphenols; weight, diameter, color, and firmness; TSS, titratable acidity (TA), and the index of maturation (TSS/TA) of berries.

\subsection{Total anthocyanins}

The evaluation of the total anthocyanin concentration in the grape berry skin was performed according to a method described by Peppi et al. (2006). From each sample, $3 \mathrm{~g}$ of the berry skin was peeled off and washed with distilled water, followed by a quick wash with de-ionized water and then dried with sterilized tissues. Further, $30 \mathrm{~mL}$ acidified 


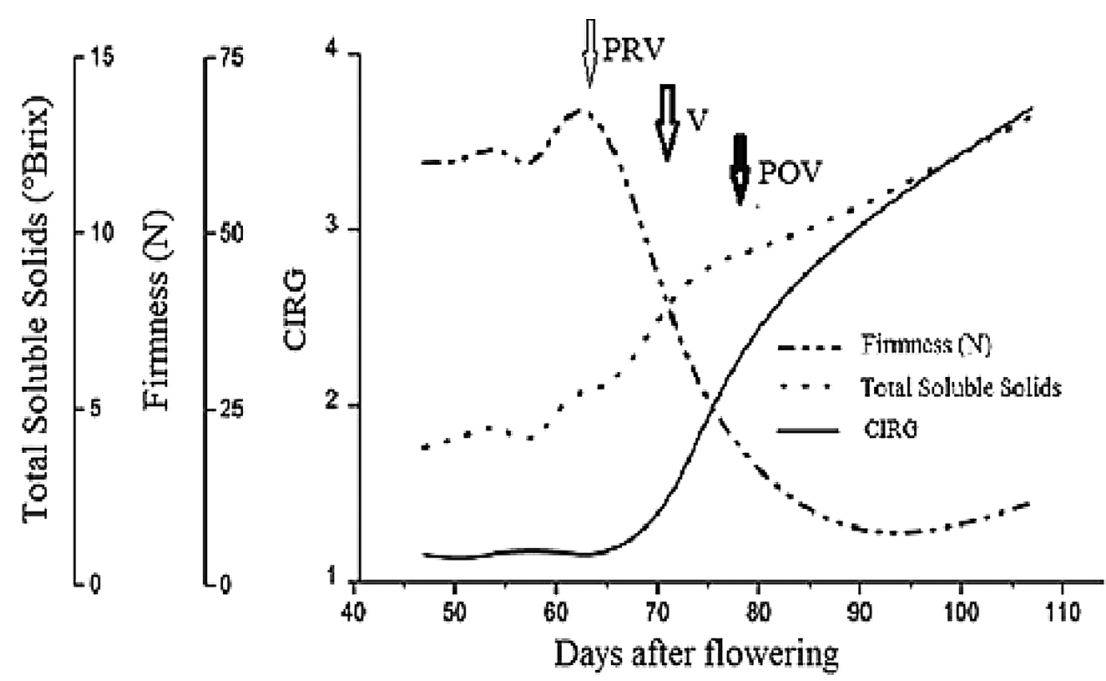

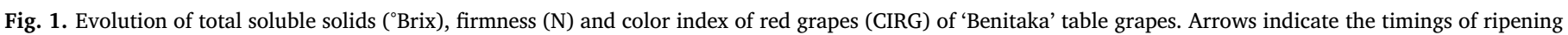
where the treatments of $S$-ABA $400 \mathrm{mg} \mathrm{L}^{-1}$ were applied. PRV $=$ Pre-veraison; $\mathrm{V}=$ Veraison and POV $=$ Post-veraison.

methanol $(\mathrm{HCl} 1 \%+$ methanol $99 \%)$ was added to the peeled berry skin and kept in the dark for $48 \mathrm{~h}$. The values were recorded using a spectrophotometer Genesys ${ }^{\mathrm{TM}}$ 10S UV-VIS ${ }^{\circledR}$ (Thermo Scientific, USA) at $520 \mathrm{~nm}$, and the results were expressed as milligrams of total anthocyanins as malvidin-3-glucoside per gram of berry skin $\left(\mathrm{mg}^{-\mathrm{g}^{-1}}\right)$. The daily rate of anthocyanin accumulation was calculated by subtracting former readings from the latter and dividing it by the number of days, i.e., 7 days. The results were expressed in milligrams of malvidin-3glucoside per gram of berry skin per day $\left(\mathrm{mg} \mathrm{g}^{-1} \mathrm{day}^{-1}\right)$.

\subsection{Total polyphenols}

The evaluation of the total polyphenol concentration in the pulp and skin of berries was based on the Folin-Ciocauteau method (Bucic-Kojic et al., 2007; Borges et al., 2013). The samples were macerated and $5 \mathrm{~g}$ of this sample was homogenized with $50 \mathrm{~mL}$ of $50 \%$ ethanol in a blender for $2 \mathrm{~min}$ and centrifuged at $3500 \mathrm{rpm}$ for $5 \mathrm{~min}$. A $0.2 \mathrm{~mL}$ aliquot of the extract was mixed with $1.8 \mathrm{~mL}$ distilled water and $10 \mathrm{~mL}$ of 10 -fold diluted Folin-Ciocalteau reagent. In addition, after $30 \mathrm{~s}$ to $8 \mathrm{~min}, 8 \mathrm{~mL}$ of $7.5 \% \mathrm{Na}_{2} \mathrm{CO}_{3}$ solution was added. All test tubes containing the mixture were shaken for $10 \mathrm{~s}$ on the vortex and kept in the darkness for $2 \mathrm{~h}$. Further, the absorbance of each sample was measured after $15 \mathrm{~min}$ using a spectrophotometer Genesys ${ }^{\mathrm{TM}}$ 10S UV-VIS ${ }^{\circledR}$ (Thermo Scientific, USA) at $765 \mathrm{~nm}$ against a blank sample. Total polyphenols was determined from the calibration curve obtained with gallic acid; readings were expressed as $\mathrm{mg} .100 \mathrm{~g}^{-1}$ of berries (gallic acid equivalents).

\subsection{Color, mass, diameter, and firmness of berries}

The berry color was analyzed using a colorimeter CR-10 (Minolta ${ }^{\circledR}$, Tokyo, Japan) to obtain the following variables from the equatorial portion of berries ( $\mathrm{n}=2$ per berry): $L^{*}$ (lightness), $C^{*}$ (chroma), and $h^{\circ}$ (hue) (Koyama et al., 2014). Lightness values range from 0 (black) to 100 (white). Chroma indicates the purity or intensity of color; the distance from gray (achromatic) toward a pure chromatic color is calculated from the $a^{*}$ and $b^{*}$ values of the CIELab scale system, which starts from zero for a completely neutral color, and does not have an arbitrary end, but intensity increases with magnitude. Hue refers to the color wheel and is measured in angles; green, yellow, and red correspond to 180,90 , and $0^{\circ}$, respectively (Mcguire, 1992; Lancaster et al., 1997; Peppi et al., 2006). The CIRG was calculated using the formula: CIRG $=\left(180-h^{\circ}\right) /\left(L^{*}+C^{*}\right)$ (Carreño et al., 1995), and the 'Benitaka' berry color was classified into 5 categories according to the CIRG values, i.e., green-yellow ( $<1.5$ ), pink (1.5 to 2.5$)$, red (2.5 to 3.5 ), violet (3.5 to 4.5), and dark violet (> 5.0) (Carreño et al., 1998). Further, the rate of the CIRG was calculated by subtracting the final CIRG value from the initial readings and dividing it by the total number of days it took. These results were expressed as CIRG.day ${ }^{-1}$.

The diameter $(\mathrm{mm})$ and mass $(\mathrm{g})$ of berries were measured with a digital caliper and digital scale, respectively. The firmness of grapes berry was determined using a texture analyzer TA.XT plus (Stable Micro Systems, Surrey, U.K.) with a cylindrical probe (35 mm diameter, P35). These berries were compressed in their equatorial diameter at $1 \mathrm{~mm} . \mathrm{s}^{-1}$ (probe speed), and the deformation rate of $20 \%$ of their equatorial diameter, and the firmness was expressed as the force $(\mathrm{N})$ to deform the berries (Lijavetzky et al., 2012).

\subsection{Total soluble solids (TSS), titratable acidity (TA), and maturation index (TSS/TA) of berries}

The TSS contents were calculated using a digital refractometer DR301-95 (Krüss Optronic, Germany) by crushing the berries of each plot, and the results were expressed in ${ }^{\circ} \mathrm{Brix}$. The TA was evaluated by titrating the solution extracted from the berries with standardized $0.1 \mathrm{~N}$ $\mathrm{NaOH}$ in semi-automatic titrator. The titration was stopped when the $\mathrm{pH}$ of the solution reached 8.2; results were expressed as a percentage of tartaric acid (Instituto Adolfo Lutz, 2008). The maturation index was obtained from the ratio of TSS/TA.

\subsection{Statistical analysis}

The data were submitted to analysis of variance and means were compared by Tukey's test at $5 \%$ probability (Gomes, 2009). In addition, a simple correlation analysis was performed between CIRG and total anthocyanins.

\section{Results and discussion}

\subsection{Anthocyanin response to $S-A B A$ application at different timings of veraison}

The anthocyanin contents of 'Benitaka' table grapes during the summer season 2015 and off-season 2016 were significantly higher (three-fold) in S-ABA treated berries as compared to those in nontreated ones (control) (Table 1). However, results derived from these treatments are statistically at par with each other, implying the availability of a longer window for application from PRV to POV. This 
Table 1

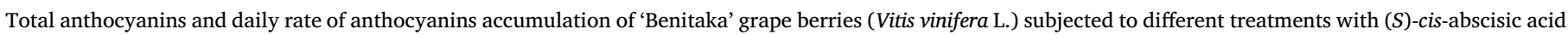
$(S$-ABA) at different timings. Summer crop 2015 and off-season crop 2016.

\begin{tabular}{|c|c|c|c|c|}
\hline \multirow[t]{2}{*}{ Treatments (timings of $S$-ABA $400{\mathrm{mg} . \mathrm{L}^{-1}}^{-1}$ application) ${ }^{1}$} & \multicolumn{2}{|c|}{ Total anthocyanins (mg. $\mathrm{g}^{-1}$ of skin) } & \multicolumn{2}{|c|}{ Daily rate of anthocyanins accumulation $\left(\mathrm{mg} \mathrm{g}^{-1}\right.$ of skin day $\left.{ }^{-1}\right)$} \\
\hline & 2015 & 2016 & 2015 & 2016 \\
\hline Control & $0.8 \pm 0.1 \mathrm{~b}$ & $1.2 \pm 0.4 \mathrm{~b}$ & $0.027 \pm 0.01 \mathrm{~b}$ & $0.032 \pm 0.01 \mathrm{c}$ \\
\hline Pre-veraison (PRV) & $3.4 \pm 0.2 \mathrm{a}$ & $3.0 \pm 0.2 \mathrm{a}$ & $0.114 \pm 0.01 \mathrm{a}$ & $0.082 \pm 0.01 \mathrm{a}$ \\
\hline Veraison (V) & $3.0 \pm 0.7 \mathrm{a}$ & $3.1 \pm 0.2 \mathrm{a}$ & $0.101 \pm 0.02 \mathrm{a}$ & $0.084 \pm 0.01 \mathrm{a}$ \\
\hline Post-veraison (POV) & $2.3 \pm 0.6 \mathrm{a}$ & $2.5 \pm 0.3 \mathrm{a}$ & $0.078 \pm 0.02 \mathrm{a}$ & $0.068 \pm 0.01 \mathrm{~b}$ \\
\hline F value & $33.37^{*}$ & $33.66^{*}$ & $17.85^{*}$ & $33.69^{*}$ \\
\hline
\end{tabular}

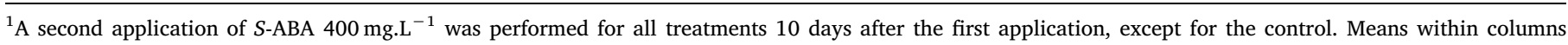
followed by different letters differ significantly by Tukey's test $(p<0.05)$. *: significant $(p<0.05)$.

increase in anthocyanin is explained by the fact that the application of $S$-ABA, at different time points during maturation, enhances the level of secondary metabolites in grapes, specifically by triggering the biosynthesis of anthocyanins (Tecchio et al., 2017).

The results also show that the daily rate of anthocyanin accumulation followed the same pattern as that of the total anthocyanin contents in 'Benitaka' grapes. The daily rates of anthocyanin accumulation during 2015 and 2016 seasons were significantly higher in S-ABA treated berries than the control, at different timings of veraison. During the 2015 season, the PRV treatment had superior daily anthocyanin accumulation, which was statistically similar to that of at V and POV, and all were significantly higher than control. However, during the 2016 season, $S$-ABA treated berries at V were recorded to have the highest daily anthocyanin accumulation (a very slight edge over the $S$ ABA treated berries at PRV). However, the $S$-ABA treated berries at POV resulted in a low rate of daily anthocyanin accumulation compared to that in berries treated at PRV and V.

Untreated berries were recorded as having the lowest rate of daily anthocyanin accumulation among all treatments. There is a substantial difference between the daily rates of anthocyanin accumulation during 2015 and 2016 seasons because during the summer season 2015, berries reached to full ripeness 41 days after their first treatment, whereas during the off-season in 2016, it took only 34 days (Table 1).

Some grape cultivars respond well to even a single application of $S$ ABA in terms of anthocyanin accumulation, whereas others may require multiple applications to demonstrate such benefits. This increase in the anthocyanin contents of 'Benitaka' table grapes upon application of $S$ $\mathrm{ABA}$ at PRV and $\mathrm{V}$ could be because grapes tissues are more responsive to the ABA stimuli for anthocyanin biosynthesis, when they are still in the early ripening stages (Yamamoto et al., 2015). ABA plays a key role in regulating a number of genes at the onset of veraison, including those involved in anthocyanin biosynthesis and their signaling pathway (Gambetta et al., 2010). In addition, this plant growth regulator reinforces the accumulation of the transcription factor $V v M Y B A 1$, a regulator of UFGT gene expression (Boss et al., 1996b; Kobayashi et al., 2002; Jeong et al., 2004; Azuma et al., 2007; Koyama et al., 2018), which interacts with the promoter regions of UFGT and other genes involved in the anthocyanin biosynthesis.

\subsection{Berry color response towards S-ABA application at different timings of veraison}

For both seasons, the CIRG of 'Benitaka' grape berries treated with $S$-ABA at different timings was higher in comparison to that of the control (Table 2). According to the grape color classification described by Carreño et al. (1998) based on CIRG values, berries treated with $S$ ABA in the season 2015 at any time of veraison (PRV, V and POV) showed a dark violet color, whereas control berries were red. Similarly, results for the season 2016 demonstrated that $S$-ABA treated berries presented a dark violet color, regardless of the application time at veraison (PRV, V, and POV), and even though control berries showed a violet color in this season, they were still inferior to $S$-ABA treated berries in terms of color development. The CIRG values of all $S$-ABA treated berries showed statistically similar results to each another, and were different from the control. However, during the 2016 season, $S$ $\mathrm{ABA}$ applied at PRV and V presented statistically similar results, but not compared to POV and the control. Treatments of $S$-ABA at different timings of veraison enhanced CIRG more quickly as compared to the control. Even at the time of harvest, untreated berries had green patches, whereas the color coverage of $S$-ABA treated bunches was more uniform (Figs. 2 and 3).

Considering the daily rate of CIRG or daily color development for the 2015 season, the means observed for the $S$-ABA treated berries, either at PRV, V, or POV, were higher to control, but at par among themselves, whereas, during the off-season 2016, the treated berries at PRV showed higher daily CIRG values among all the other treatments (Table 2).

Starting from the first application, the development of anthocyanins and color were closely related. The application of $S$-ABA at PRV, V, or POV with an additional second application significantly increased the anthocyanin contents and color of the 'Isabella' grapes (Yamamoto et al., 2015). Multiple applications of $S$-ABA improved grape color more rapidly and strongly as compared to a single application in table grapes (Roberto et al., 2013). From our results, it was noted that berries treated with $S$-ABA at PRV and $\mathrm{V}$ were more responsive to treatments as compared to those treated with $S$-ABA at POV, suggesting that genes responsible for the anthocyanin biosynthesis in 'Benitaka' table grapes can be triggered efficiently during the early stage of berry maturation.

Moreover, we demonstrated that good improvements in berry color can be achieved when $S$-ABA is applied across a wider range of ripening stages, from PR to POV, which represents a period of three weeks. This is an important observation because some weather conditions, such as rainy or windy days, as well a large vineyard area, can make the job difficult to perform in a short period of time.

The darker color of grape berries is associated with the higher contents of anthocyanins present in the skin (Olivares et al., 2017). It is well known that anthocyanins are associated with berry color, and this codependence was demonstrated when the correlation analysis between the CIRG and total anthocyanins accumulation was conducted (Fig. 4), wherein during both seasons, the relationship between these two variables was highly significant. Nevertheless, high total anthocyanin contents are responsible for the darker color of grape berries and our analysis supports that hypothesis.

\subsection{Lightness $\left(L^{*}\right)$, chroma $\left(C^{*}\right)$ and hue angle $\left(h^{\circ}\right)$ of berries}

Color quality analysis for both seasons suggests that lightness values among all the grapes decreased over time, starting from $\mathrm{V}$ until harvest (Table 3). However, it has been confirmed that the two applications of $S$-ABA at different timings of V significantly decrease $L$ * values (Tecchio et al., 2017).

After applying $S$-ABA to the grapes, the $L *$ decreased sharply among 
Table 2

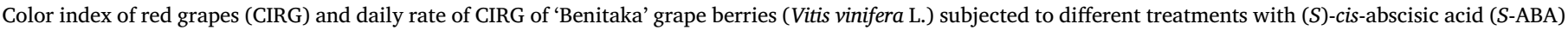
at different timings. Summer crop 2015 and off-season crop 2016.

\begin{tabular}{|c|c|c|c|c|}
\hline \multirow[t]{2}{*}{ Treatments (timings of $S$-ABA $400 \mathrm{mg} \cdot \mathrm{L}^{-1}$ application) ${ }^{1}$} & \multicolumn{2}{|l|}{ CIRG } & \multicolumn{2}{|c|}{ Daily rate of CIRG (CIRG day ${ }^{-1}$ ) } \\
\hline & 2015 & 2016 & 2015 & 2016 \\
\hline Control & $3.1 \pm 0.7 \mathrm{~b}$ & $4.6 \pm 0.6 \mathrm{c}$ & $0.06 \pm 0.02 \mathrm{~b}$ & $0.09 \pm 0.09 \mathrm{c}$ \\
\hline Pre-veraison (PRV) & $5.6 \pm 0.5 \mathrm{a}$ & $5.8 \pm 0.5 \mathrm{a}$ & $0.14 \pm 0.02 \mathrm{a}$ & $0.13 \pm 0.07 \mathrm{a}$ \\
\hline Veraison $(\mathrm{V})$ & $5.4 \pm 0.4 \mathrm{a}$ & $5.6 \pm 0.4 \mathrm{ab}$ & $0.14 \pm 0.02 \mathrm{a}$ & $0.12 \pm 0.06 \mathrm{~b}$ \\
\hline Post-veraison (POV) & $5.4 \pm 1.2 \mathrm{a}$ & $5.4 \pm 0.4 \mathrm{~b}$ & $0.14 \pm 0.04 \mathrm{a}$ & $0.12 \pm 0.05 \mathrm{~b}$ \\
\hline F value & $107.01 *$ & $61.29 *$ & $104.71 *$ & $61.05^{*}$ \\
\hline
\end{tabular}

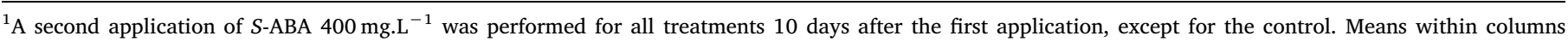
followed by different letters differ significantly by Tukey's test $(p<0.05)$. *: significant $(p<0.05)$.

all the treatments regardless of the application timings. However, untreated berries were recorded with a significantly high $L^{*}$ as compared to those of the treated grapes (Olivares et al., 2017). Lower $L^{*}$ value suggests a darker color among the $S$-ABA treated berries than that in the untreated berries, which have higher $L$ * readings (Roberto et al., 2012; Domingues Neto et al., 2017; Tecchio et al., 2017).

Lower $C^{*}$, as a result of the $S$-ABA application (Table 3 ), indicates a low color purity (Cantín et al., 2007; Ferrara et al., 2013, 2015). However, this slight change in color purity is undetectable to the naked eye and has no negative effect on the market value of the grapes (Olivares et al., 2017). Some studies have reported $S$-ABA has no effect on $h^{\circ}$ (Yamamoto et al., 2015; Tecchio et al., 2017). However, in 2015 season, the $h^{\circ}$ decreased along with $L^{*}$ (Table 3), implying a diversion from the green towards red color (Olivares et al., 2017). Meanwhile, during 2016 season, the $h^{\circ}$ differed slightly from the pattern observed in 2015 season. This phenomenon may have occurred because of the difference in weather conditions occurred during ripening between summer and off-seasons. It is widely known that anthocyanin biosynthesis is favored by lower night temperatures during off-season crop, where grape ripening takes place in autumn instead of summer in summer season crop (Koshita et al., 2007; Ricce et al., 2013; Ferrara et al., 2015).

\subsection{Mass, length, width and firmness of berries}

Various studies have shown that $S$-ABA treatments, for the improvement of color and anthocyanin concentration, do not affect other physical characteristics of berries (Sandhu et al., 2011; Roberto et al., 2012, 2013; Koyama et al., 2014; Yamamoto et al., 2015). Similar results were obtained in the current study, wherein there was no significant effect of $S$-ABA on the weight of 'Benitaka' berries (Table 4).

However, the diameter of berries showed a slightly different behavior; both length wise and width wise diameters were different among the treated berries, during the 2015 season, and no such effect was detected in berries during the 2016 season (Table 4). Thus, although $S$ ABA does not influence the length and width of berries, the weather conditions of specific season can alter these variables (Yamamoto et al., 2015).

It was observed that the berry firmness decreased in response to the $S$-ABA application (Table 4). Secondary metabolites in plants, such as anthocyanins are stored inside the cell vacuole, transported by ATPbinding cassette (ABC) transporters (Taiz and Zeiger, 2003). The $S$-ABA application improved the anthocyanin accumulation, which implies more of these compounds are stored inside the cell vacuole, thus increasing the solute concentration. As water flows from the area of low solute concentration towards the area of high solute concentration (Lodish et al., 2000), the cell vacuole must have absorbed more water from the surrounding cytoplasm and decreased the cell turgidity. This could be the reason behind the decrease in the firmness of grape berries in response to $S$-ABA treatments. In addition, it is important to mention that the berry surface was firm and no cracking was observed at the time of harvest. Although $S$-ABA decreased the berry firmness, there is
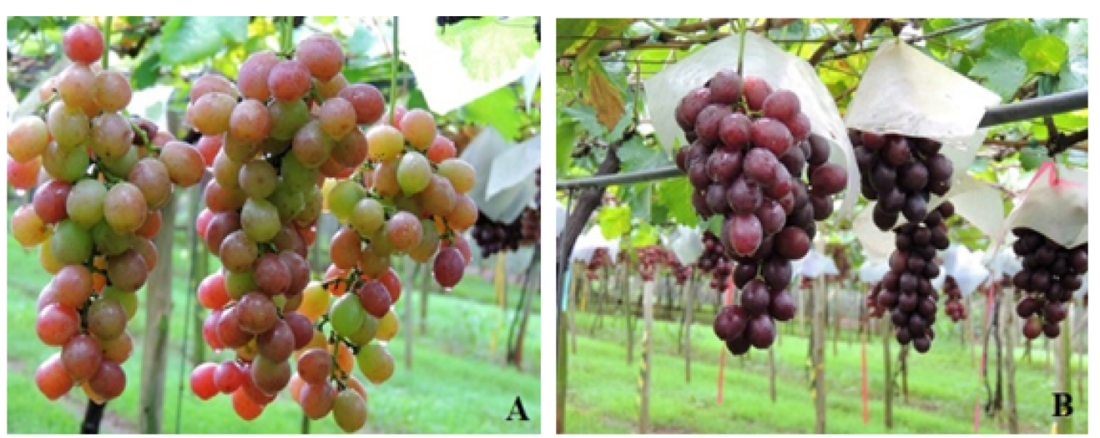

Fig. 2. Bunches of 'Benitaka' table grape subjected to different treatments with (S)-cis-abscisic acid (S-ABA $400 \mathrm{mg} \mathrm{L}^{-1}$ ) at different timings of ripening. A: Control (no application); B: At pre-veraison; C: at veraison; D: at post-veraison. A second application of $S$-ABA $400 \mathrm{mg} . \mathrm{L}^{-1}$ was performed for all treatments 10 days after the first application, except for the control. Summer crop 2015.
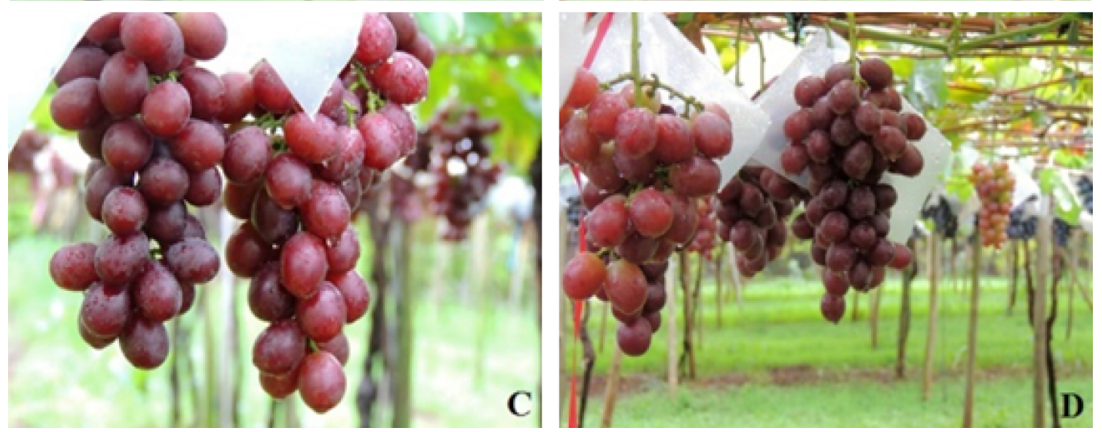


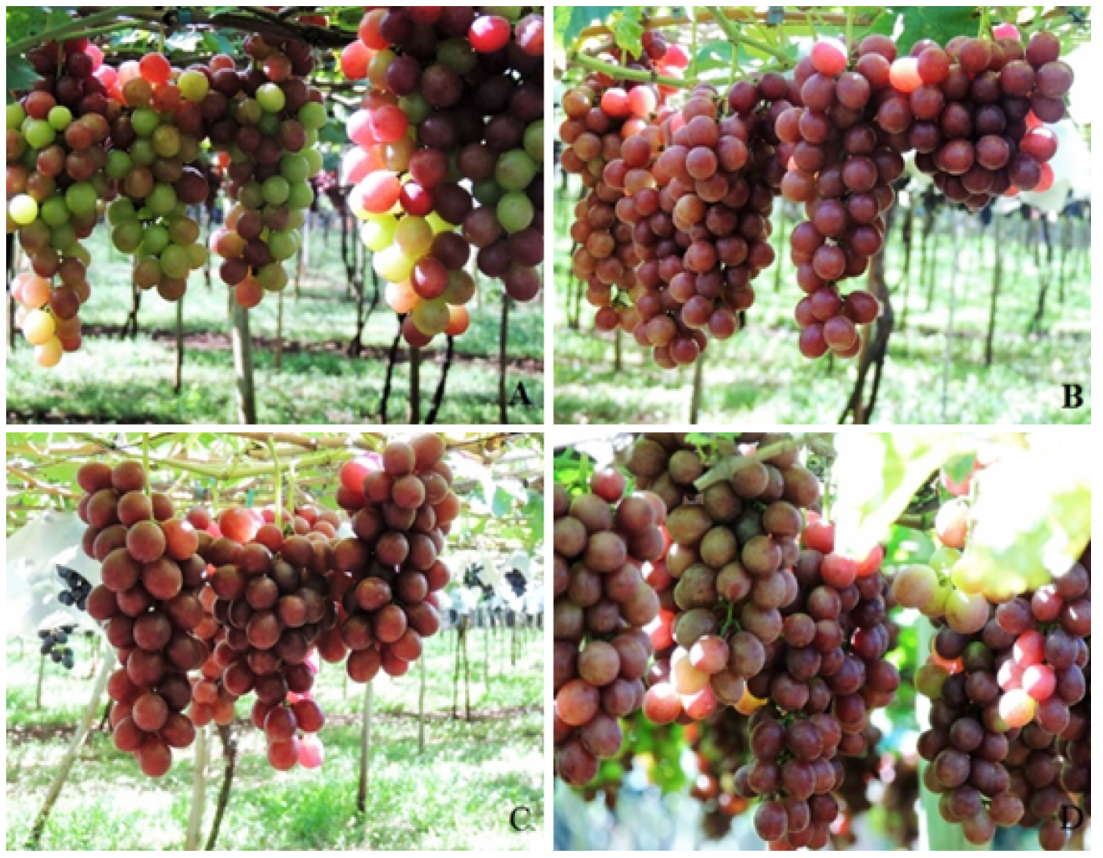

Fig. 3. Bunches of 'Benitaka' table grape subjected to different treatments with $(S)$-cis-abscisic acid (S-ABA $400 \mathrm{mg} . \mathrm{L}^{-1}$ ) at different timings of ripening. A: Control (no application); B: At pre-veraison; C: At veraison; D: at post-veraison. A second application of $S$-ABA $400 \mathrm{mg} . \mathrm{L}^{-1}$ was performed for all treatments 10 days after the first application, except for the control. Off-season crop 2016.
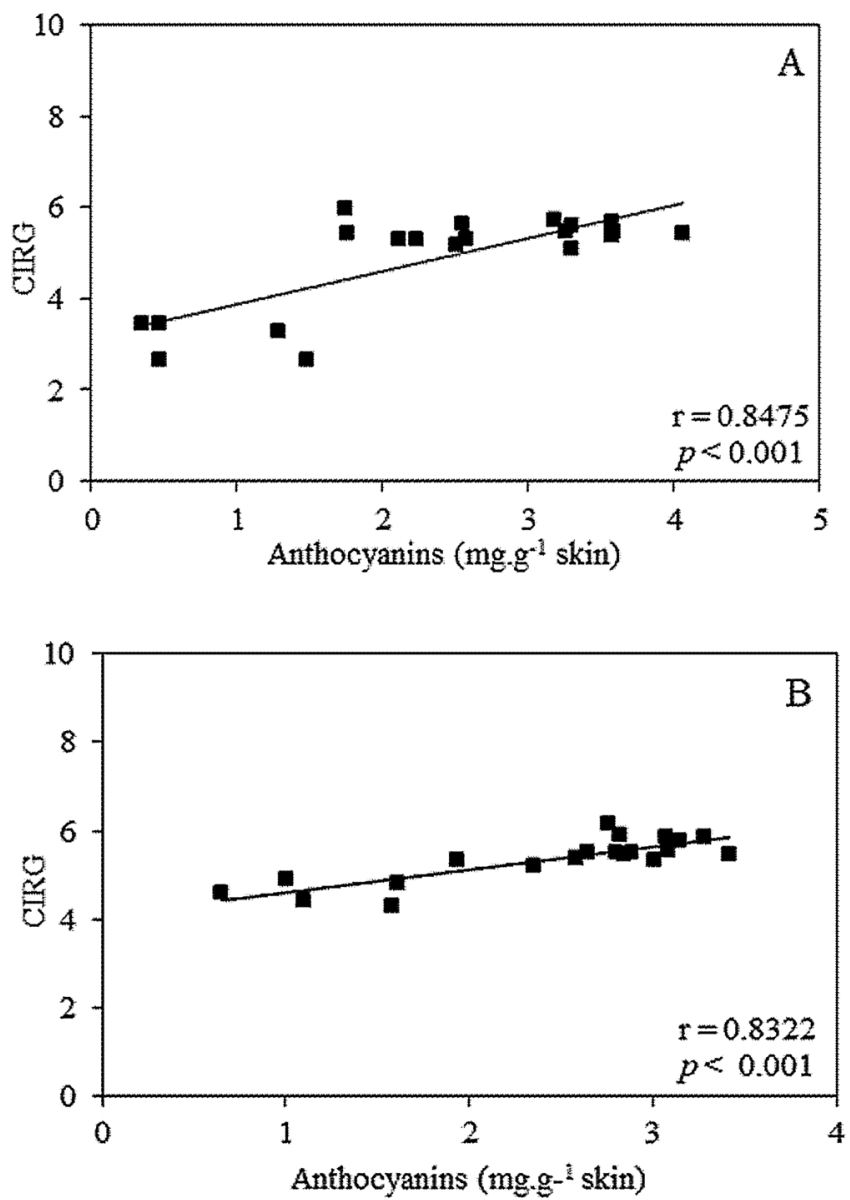

Fig. 4. Simple linear correlation between color index of red grapes (CIRG) with total anthocyanins accumulation (mg. $\mathrm{g}^{-1}$ of skin) of 'Benitaka' grape berries (Vitis vinifera L.) subjected to different treatments with (S)-cis-abscisic acid (SABA 400 mg.: L $^{-1}$ ). A: Summer crop 2015; B: Off-season crop 2016. no evidence that it negatively affected the quality or commercial value of the product.

3.5. Total soluble solids (TSS), titratable acidity (TA), index of maturation (TSS/TA), and total polyphenols of berries

There has been a little difference in the pattern followed by TSS, TA, and maturation index (TSS/TA) in both evaluated seasons (Table 5). Although TSS contents can be influenced by exogenous application of the plant growth regulator (Luan et al., 2014; Ju et al., 2016), the differences in the TSS contents observed here suggest that the change may have occurred in response to environmental stimuli rather than $S$ ABA treatment. However, the 2016 season did not show any such response, confirming our hypothesis (Koyama et al., 2014; Yamamoto et al., 2015; Zhu et al., 2016). TA and TSS/TA also followed the same pattern, in which a slight change was observed during 2015 season in these variables, while during 2016 season, no difference among treatments was noticed (Table 5).

It is important to mention that certain quality parameters can be affected by specific environmental conditions (Ju et al., 2016), and this might be the reason TA and TSS/TA also varied like TSS during the season 2015 but not season 2016. The total polyphenols of 'Benitaka' table grapes did not show any difference in the response to the $S$-ABA treatments during 2015 season. However, they varied slightly during the 2016 season, with a small margin of variation. The response of phenolic acid and its antioxidant activity depend mostly on internal factors, importantly its genotype (Xu et al., 2014). Thus, among some grapes, such as muscadine (Olivares et al., 2017), 'Malbec' (Berli et al., 2011), and 'Cabernet Sauvignon' (Deis et al., 2011; Ju et al., 2016), $S$ ABA application can increase the total polyphenols, whereas in others, such as 'Isabella' grapes, $S$-ABA application has no effect (Koyama et al., 2014; Yamamoto et al., 2015).

In general, the exogenous application of $S$-ABA shows a significant effect on the anthocyanin contents and the berry color index of 'Benitaka' table grapes, when applied around the time of veraison. Depending on the season, it was observed that early application lead to a high rate of daily anthocyanin accumulation and increased the total anthocyanin by almost three folds as compared to the control treatment. The right time of the $S$-ABA application is key for achieving these goals, when genes responsible for the anthocyanin biosynthesis are 
Table 3

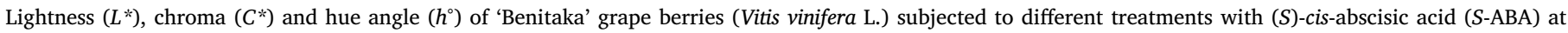
different timings. Summer crop 2015 and off-season crop 2016.

\begin{tabular}{|c|c|c|c|c|c|c|}
\hline \multirow[t]{2}{*}{ Treatments (timings of $S$-ABA $400 \mathrm{mg} \cdot \mathrm{L}^{-1}$ application) ${ }^{1}$} & \multicolumn{2}{|l|}{$L^{*}$} & \multicolumn{2}{|l|}{$C^{*}$} & \multicolumn{2}{|l|}{$h^{\circ}$} \\
\hline & 2015 & 2016 & 2015 & 2016 & 2015 & 2016 \\
\hline Control & $29.6 \pm 2.6 \mathrm{a}$ & $23.1 \pm 2.2 \mathrm{a}$ & $9.47 \pm 1.0 \mathrm{a}$ & $8.6 \pm 1.2 \mathrm{a}$ & $61.0 \pm 20.9 \mathrm{a}$ & $35.8 \pm 9.1 \mathrm{~b}$ \\
\hline Pre-veraison (PRV) & $21.0 \pm 9.7 \mathrm{~b}$ & $19.6 \pm 9.7 \mathrm{c}$ & $3.99 \pm 0.8 \mathrm{~d}$ & $4.4 \pm 1.0 \mathrm{~d}$ & $41.3 \pm 9.7 \mathrm{~b}$ & $41.1 \pm 9.7 \mathrm{a}$ \\
\hline Veraison (V) & $21.0 \pm 12.2 \mathrm{~b}$ & $20.6 \pm 7.1 \mathrm{bc}$ & $4.70 \pm 1.9 \mathrm{c}$ & $5.3 \pm 1.4 \mathrm{c}$ & $41.9 \pm 12.2 \mathrm{~b}$ & $36.7 \pm 7.1 \mathrm{ab}$ \\
\hline Post-veraison (POV) & $21.7 \pm 5.9 \mathrm{~b}$ & $20.8 \pm 6.3 \mathrm{~b}$ & $6.09 \pm 1.1 \mathrm{~b}$ & $6.5 \pm 1.5 b$ & $33.0 \pm 5.9 \mathrm{c}$ & $34.0 \pm 6.9 \mathrm{~b}$ \\
\hline F value & $177.00^{*}$ & $42.20^{*}$ & $193.82 *$ & $103.32 *$ & $38.41^{*}$ & $6.75^{*}$ \\
\hline
\end{tabular}

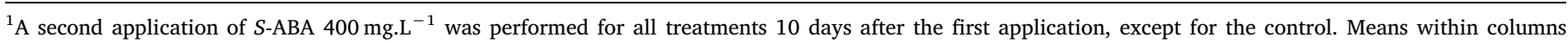
followed by different letters differ significantly by Tukey's test $(p<0.05)$. *: significant $(p<0.05)$.

Table 4

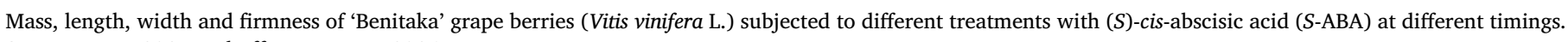
Summer crop 2015 and off-season crop 2016.

\begin{tabular}{|c|c|c|c|c|c|c|c|c|}
\hline \multirow[t]{2}{*}{ Treatments (timings of $S$-ABA $400 \mathrm{mg} \cdot \mathrm{L}^{-1}$ application) ${ }^{1}$} & \multicolumn{2}{|l|}{$\begin{array}{l}\text { Mass } \\
(\mathrm{g})\end{array}$} & \multicolumn{2}{|l|}{$\begin{array}{l}\text { Length } \\
(\mathrm{mm})\end{array}$} & \multicolumn{2}{|l|}{$\begin{array}{l}\text { Width } \\
\text { (mm) }\end{array}$} & \multicolumn{2}{|l|}{$\begin{array}{l}\text { Firmness } \\
(\mathrm{N})\end{array}$} \\
\hline & 2015 & 2016 & 2015 & 2016 & 2015 & 2016 & 2015 & 2016 \\
\hline Control & $10.4 \pm 0.7$ & $8.6 \pm 0.6$ & $28.9 \pm 3.2 \mathrm{~b}$ & $27.3 \pm 1.3$ & $23.6 \pm 1.2 \mathrm{~b}$ & $23.2 \pm 1.9$ & $11.7 \pm 1.4 \mathrm{a}$ & $10.5 \pm 1.2 \mathrm{a}$ \\
\hline Pre-veraison (PRV) & $11.6 \pm 1.1$ & $9.2 \pm 0.6$ & $30.7 \pm 1.8 \mathrm{a}$ & $27.9 \pm 1.3$ & $24.7 \pm 1.4 \mathrm{a}$ & $23.3 \pm 3.0$ & $9.6 \pm 1.4 \mathrm{c}$ & $8.8 \pm 1.1 \mathrm{c}$ \\
\hline Veraison (V) & $11.8 \pm 0.9$ & $9.8 \pm 0.5$ & $30.2 \pm 1.6 \mathrm{a}$ & $28.0 \pm 1.4$ & $24.7 \pm 1.4 \mathrm{a}$ & $24.0 \pm 1.5$ & $9.9 \pm 1.1 \mathrm{c}$ & $9.3 \pm 0.8 \mathrm{bc}$ \\
\hline Post-veraison (POV) & $10.1 \pm 0.6$ & $8.5 \pm 0.8$ & $29.6 \pm 1.5 \mathrm{ab}$ & $27.6 \pm 3.4$ & $23.3 \pm 1.1 \mathrm{~b}$ & $23.8 \pm 1.2$ & $10.8 \pm 1.6 \mathrm{~b}$ & $9.5 \pm 1.3 \mathrm{~b}$ \\
\hline F value & $4.14^{\mathrm{ns}}$ & $1.5^{\mathrm{ns}}$ & $9.79^{*}$ & $1.1^{\mathrm{ns}}$ & $16.13^{*}$ & $2.0^{\mathrm{ns}}$ & $24.63^{*}$ & $22.72^{*}$ \\
\hline
\end{tabular}

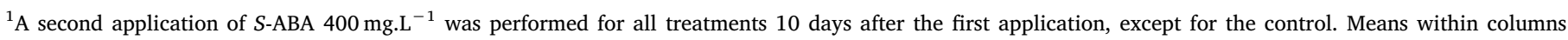
followed by different letters differ significantly by Tukey's test $(p<0.05)$. *: significant $(p<0.05)$. ns: non-significant.

Table 5

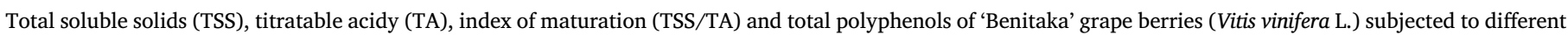
treatments with $(S)$-cis-abscisic acid (S-ABA) at different timings. Summer crop 2015 and off-season crop 2016.

\begin{tabular}{|c|c|c|c|c|c|c|c|c|}
\hline \multirow{2}{*}{$\begin{array}{l}\text { Treatments (timings of } S \text {-ABA } \\
400 \mathrm{mg}^{-\mathrm{L}^{-1}} \text { application) }{ }^{1}\end{array}$} & \multicolumn{2}{|l|}{ TSS $\left({ }^{\circ}\right.$ Brix $)$} & \multicolumn{2}{|c|}{ TA (\% of tartaric acid) } & \multicolumn{2}{|c|}{ Index of maturation (TSS/TA) } & \multicolumn{2}{|c|}{ Total polyphenols (mg.100 $\mathrm{g}^{-1}$ ) } \\
\hline & 2015 & 2016 & 2015 & 2016 & 2015 & 2016 & 2015 & 2016 \\
\hline Control & $13.4 \pm 0.4 \mathrm{~b}$ & $14.3 \pm 1.4$ & $0.74 \pm 0.08 \mathrm{a}$ & $0.67 \pm 0.05$ & $18.4 \pm 2.5 \mathrm{c}$ & $21.4 \pm 3.2$ & $0.25 \pm 0.01$ & $0.14 \pm 0.01 \mathrm{~b}$ \\
\hline Pre-veraison (PRV) & $13.5 \pm 0.4 \mathrm{ab}$ & $15.0 \pm 0.3$ & $0.53 \pm 0.05 \mathrm{~b}$ & $0.66 \pm 0.07$ & $25.8 \pm 3.1 \mathrm{ab}$ & $21.7 \pm 1.7$ & $0.24 \pm 0.03$ & $0.16 \pm 0.02 \mathrm{ab}$ \\
\hline Veraison (V) & $14.1 \pm 0.5 \mathrm{a}$ & $15.7 \pm 0.8$ & $0.52 \pm 0.07 \mathrm{~b}$ & $0.73 \pm 0.01$ & $27.5 \pm 4.7 \mathrm{a}$ & $21.5 \pm 1.3$ & $0.23 \pm 0.04$ & $0.19 \pm 0.03 \mathrm{ab}$ \\
\hline Post-veraison (POV) & $13.2 \pm 0.3 \mathrm{~b}$ & $15.4 \pm 0.5$ & $0.63 \pm 0.05 \mathrm{ab}$ & $0.73 \pm 0.02$ & $21.1 \pm 1.6 \mathrm{bc}$ & $21.4 \pm 1.0$ & $0.22 \pm 0.01$ & $0.20 \pm 0.02 \mathrm{a}$ \\
\hline F value & $6.80 *$ & $2.40^{\mathrm{ns}}$ & $12.17^{*}$ & $4.26^{\mathrm{ns}}$ & $14.89^{*}$ & $0.58^{\text {ns }}$ & $0.87^{\text {ns }}$ & $6.59 *$ \\
\hline
\end{tabular}

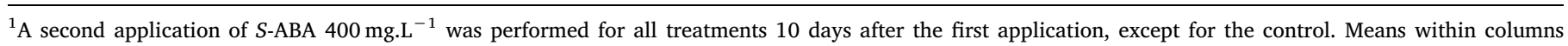
followed by different letters differ significantly by Tukey's test $(p<0.05)$. *: significant $(p<0.05)$. ns: non-significant.

receptive to these hormones, and better results were obtained when $S$ ABA was applied at PRV or V. Sugars and ABA levels are believed to trigger the anthocyanin accumulation in the skin of grape berries, by activating the gene expressions involved in the anthocyanin biosynthesis (Keller, 2015). Applying S-ABA to the berries around the veraison time, when the genes are already active, increases their efficiency. A study performed on 'Crimson Seedless' showed that three weeks after the application of $S$-ABA, UFGT levels of the treated grapes decreased (Peppi et al., 2008b). For this reason, a second application of $S$-ABA at a time when the concentrations of endogenous ABA are close to maximum levels or beginning to decrease, possibly contribute to the increase in the gene expression. A stronger correlation exists between anthocyanin and color development, as well as on daily basis. TSS, TA, index of maturation, and total polyphenols were not significantly affected by the use of $S$-ABA. Similarly, other physical attributes like length, width, and berry mass did not show any significant change. However, berry firmness slightly varied in response to these treatments, but not to the extent where it compromised the berry quality for commercial use. There is a slight difference in berry color between the two seasons evaluated, and this difference is probably due to the different weather conditions in which the ripening takes place in both seasons.

\section{Conclusions}

The exogenous application of $S$-ABA from pre to post-veraison can significantly enhance the contents and rates of total anthocyanins accumulation and color index of 'Benitaka' table grape, but applications at pre-veraison and at veraison result in a higher response.

A strong correlation exists between the anthocyanin concentration and color index of the skin of grape berries, however, the main physicochemical characteristics of berries are not significantly affected by treatment with $S$-ABA.

The berry firmness varies in response to the $S$-ABA application, but not to an extent at which it compromises the berry quality for commercial use.

\section{Acknowledgments}

The authors thank the Brazilian National Council for Scientific and Technological Development (CNPq) and The World Academy of Sciences (TWAS) for financial support. 


\section{References}

Azuma, A., Kobayashi, S., Yakushiji, H., Yamada, M., Mitani, N., Sato, A., 2007. VvmybA1 genotype determines grape skin color. Vitis 46 (3), 154-155.

Ban, T., Ishimaru, M., Kobayashi, S., Shiozak, S., Goto-Yamamoto, N., Horiuchi, S., 2003. Abscisic acid and 2,4-dichlorohenoxyacetic acid affect the expression of anthocyanin biosynthetic pathway genes in 'Kyoho' grape berries. J. Hortic. Sci. Biotechnol. 78, 586-589. https://doi.org/10.1080/14620316.2003.11511668.

Berli, F.J., Fanzone, M., Piccoli, P., Bottini, R., 2011. Solar UVB and ABA involved in phenol metabolism ofVitis vinifera $\mathrm{L}$. increasing biosynthesis of berry skin polyphenols. J. Agric. Food Chem. 59, 4874-4884. https://doi.org/10.1021/jf200040z.

Boss, P.K., Davies, C., Robinson, S., 1996a. Analysis of the expression of anthocyanin pathway genes in developing Vitis vinifera L. cv. Shiraz grape berries and the implications for pathway regulation. Plant Physiol. 111, 1059-1066. https://doi.org/ 10.1104/pp.111.4.1059.

Boss, P.K., Davies, C., Robinson, S., 1996b. Expression of anthocyanin biosynthesis pathway genes in red and white grapes. Plant Mol. Biol. 32, 565-569. https://doi. org/10.1007/BF00019111.

Boss, P.K., Davies, C., 2009. Molecular biology of anthocyanin accumulation in grape berries. In: Roubelakis-Angelakis, K.A. (Ed.), Grapevine Molecular Physiology \& Biotechnology, $2^{\text {nd }}$ ed. Springer, Berlin, pp. 263-292.

Borges, R.S., Da Silva, G.A., Roberto, S.R., De Assis, A.M., Yamamoto, L.Y., 2013. Phenolic compounds, favorable oxi-redox activity and juice color of 'Concord' grapevine clones. Sci. Hort. 161, 161-188. https://doi.org/10.1016/j.scienta.2013.07.011.

Bucic-Kojic, A., Planinić, M., Tomas, S., Bilić, M., Velić, D., 2007. Study of solid liquid extraction kinetics of total polyphenols from grapes seeds. J. Food Eng. 8 (1), 236-242. https://doi.org/10.1016/j.jfoodeng.2006.10.027.

Carreño, J., Martínez, A., Almela, L., Fernández-López, J.A., 1995. Proposal of an index for the objective evaluation of the color of red table grapes. Food Res. Int. 28 (4), 373-377. https://doi.org/10.1016/0963-9969(95)00008-A.

Carreño, J., Faray, S., Martinez, A., 1998. Effects of girdling and covering mesh on ripening, color and fruit characteristics of 'Italia' grapes. J. Hort. Sci. Biotechnol. 73 (1), 103-106. https://doi.org/10.1080/14620316.1998.11510951.

Castellarin, S.D., Matthews, M.A., Di Gaspero, G., Gambetta, G.A., 2007a. Water deficits accelerate ripening and induce changes in gene expression regulating flavonoid biosynthesis in grape berries. Planta 227, 101-112. https://doi.org/10.1007/s00425007-0598-8.

Castellarin, S.D., Pfeiffer, A., Sivilotti, P., Degan, M., Peterlunger, E., Di Gaspero, G., 2007b. Transcriptional regulation of anthocyanin biosynthesis in ripening fruits of grapevine under seasonal water deficit. Plant Cell Environ. 30, 1381-1399. https:// doi.org/10.1111/j.1365-3040.2007.01716.x.

Cantín, M.C., Fidelibus, M.W., Crisosto, C.H., 2007. Application of abscisic acid (ABA) at veraison advanced red color development and maintained postharvest quality of 'Crimson Seedless' grapes. Postharvest Biol. Technol. 46, 237-241. https://doi.org/ 10.1016/j.postharvbio.2007.05.017.

Chira, K., Pacella, N., Jourdes, M., Teissedre, P.L., 2011. Chemical and sensory evaluation of Bordeaux wines (Cabernet Sauvignon and Merlot) and correlation with wine age. Food Chem. 126, 1971-1977. https://doi.org/10.1016/j.foodchem.2010.12.056.

Deis, L., Canagnaro, B., Rubens, B., Wuilloud, R., Silva, M.F., 2011. Water deficit and exogenous ABA significantly affect grape and wine phenolic composition under in field and invitro conditions. Plant Growth Regul. 65, 11-21. https://doi.org/10. 1007/s10725-011-9570-5.

Domingues Neto, F.J., Tecchio, M.A., Pimentel Junior, A., Vedoato, B.T.F., Lima, G.P., Roberto, S.R., 2017. Effect of ABA on color of berries and in the anthocyanin accumulation and total phenolic compounds of 'Rubi' table grape (Vitis vinifera). Aust. J. Crop Sci. 1, 199-205.

Ferrara, G., Mazzeo, A., Matarrese, A.M.S., Pacucci, C., Pacifico, A., Gambacorta, G., Faccia, M., Trani, A., Gallo, V., Cafagna, I., Mastrorilli, P., 2013. Application of abscisic acid (S-ABA) to 'Crimson Seedless' grape berries in a Mediterranean climate: effects on color, chemical characteristics, metabolic profile, and $S$-ABA concentration. J. Plant Growth Regul. 32, 491-505. https://doi.org/10.1007/s00344-012-9316-2.

Ferrara, G., Mazzeo, A., Matarrese, A.M.S., Pacucci, C., Punzi, R., Faccia, M., Trani, A. Gambacorta, G., 2015. Application of abscisic acid (S-ABA) and sucrose to improve color, anthocyanin content and antioxidant activity of cv. Crimson seedless grape berries. Aust. J. Grape Wine Res. 21, 18-29. https://doi.org/10.1111/ajgw.12112.

Flamini, R., Mattivi, F., Rosso, M.D., Arapitsas, P., Bavaresco, L., 2013. Advanced knowledge of three important classes of grape phenolics: anthocyanins, stilbenes and flavonols. Int. J. Mol. Sci. 14, 19651-19669 https://dx.doi.org/ $10.3390 \% 2 F i j m s 141019651$

Gambetta, G.A., Matthews, M.A., Shaghasi, T.H., Mcelrone, A.J., Castellarin, S.D., 2010. Sugar and abscisic acid signaling orthologs are activated at the onset of ripening in grape. Planta 232, 219-234. https://doi.org/10.1007/s00425-010-1165-2.

Gomes, F.P., 2009. Curso de estatística experimental, $15^{\text {th }}$ ed. FEALO, Piracicaba.

Huang, X.M., Huang, H.B., 2001. Early post-veraison growth in grapes: evidence for a two-step mode of berry enlargement. Aust. J. Grape Wine Res. 7 (3), 132-136. https://doi.org/10.1111/j.1755-0238.2001.tb00200.x.

Instituto Adolfo Lutz, 2008. Métodos químicos e físicos para análise dos alimentos, 3 ed. Instituto Adolfo Lutz, São Paulo.

Jeong, S.T., Goto-Yamamoto, N., Kobayashi, S., Esaka, M., 2004. Effects of plant hormones and shading on the accumulation of anthocyanins and the expression of anthocyanin biosynthetic genes in grape berry skin. Plant Sci. 167, 247-252.

Ju, Y.L., Liu, M., Zhao, H., Meng, J.F., Fang, Y.L., 2016. Effect of exogenous abscisic acid and methyl jasmonate on anthocyanin composition, fatty acids, and volatile compounds of cabernet sauvignon (Vitis vinifera L.) grape berries. Molecules 21 (10), 1354. https://doi.org/10.3390/molecules 21101354 .
Keller, M., 2015. The Science of Grapevines: Anatomy and Physiology, 2nd ed. Elsevier Academic Press, London.

Kishino, A.A., Marur, C.J., Roberto, S.R., 2019. Características da planta. In: Kishino, A.Y., Carvalho, S.L.C., Roberto, S.R. (Eds.), Viticultura Tropical: o sistema de produção de uvas de mesa do Paraná. IAPAR, Londrina, pp. 155-249. https://doi. org/10.3390/agronomy9040164.

Kobayashi, S., Ishimaru, M., Hiraoka, C., Honda, C., 2002. MYB-related genes of the Kyoho grape (Vitis labruscana) regulate anthocyanin biosynthesis. Plant Sci. 215, 924-933. https://doi.org/10.1007/s00425-002-0830-5.

Koshita, Y., Asakura, T., Fukuda, H., Tsuchida, Y., 2007. Nighttime temperature treatment of fruit cluster of 'Aki Queen' grapes during maturation and its effect on the skin color and abscisic acid content. Vitis 46, 208-209.

Koyama, R., Assis, A.M., Yamamoto, L.Y., Borges, W.F., Borges, R.S., Prudêncio, S.H., Roberto, S.R., 2014. Exogenous abscisic acid increases the anthocyanin concentration of berry and juice from 'Isabel' grapes (Vitis labrusca L.). HortScience 49 (4), 460-464 https://doi.org/10.21273/HORTSCI.49.4.460.

Koyama, R., Roberto, S.R., de Souza, R.T., Borges, W.F.S., Anderson, M., Waterhouse, A.L., Cantu, D., Fidelibus, M.W., Blanco-Ulate, B., 2018. Exogenous Abscisic Acid promotes anthocyanin biosynthesis and increased expression of flavonoid synthesis genes in Vitis vinifera $\times$ Vitis labrusca table grapes in a subtropical region. Front. Plant Sci. 9, e323. https://doi.org/10.3389/fpls.2018.00323.

Koyama, R., Assis, A.M., Colombo, R.C., Borges, W.F., Borges, R.S., Silvestre, J.P., Hussain, I., Shahab, M., Ahmed, S., Prudêncio, S.H., Souza, R.T., Roberto, S.R., 2019. Abscisic acid application affects the color and acceptance of the new hybrid 'BRS Melodia' seedless grape grown in a subtropical region. HortScience 54 (6), 1055-1060. https://doi.org/10.21273/HORTSCI13872-19.

Lancaster, J.E., Lister, C., Reay, P.F., Triggs, C.M., 1997. Influence of pigment composition on skin color in a wide range of fruits and vegetables. J. Am. Soc. Hortic. Sci. 122, 594-598.

Leão, P.C.S., Soares, J.M., Rodrigues, B.L., 2009. Principais cultivares. In: Soares, J.M., Leão, P.C.S. (Eds.), A Vitivinicultura no Semiárido Brasileiro. Embrapa Informação Tecnológica, Brasília.

Lecourieux, F., Kappel, C., Lecourieux, D., Serrano, A., Torres, E., Arce-Johnson, P., 2014. An update on sugar transport and signalling in grapevine. J. Exp. Bot. 65, 821-832. https://doi.org/10.1093/jxb/ert394.

Lijavetzky, D., Carbonell-Bejerano, P., Grimplet, J., Bravo, G., Flores, P., Fenoll, J., Hellín, P., Oliveros, J.C., Martínez-Zapater, J.M., 2012. Berry flesh and skin ripening features in Vitis vinifera as assessed by transcriptional profiling. PLoS One 7 (10), e1371. https://doi.org/10.1371/journal.pone.0039547.

Lodish, H., Berk, A., Zipursky, S.L., Matsudaira, P., Baltimore, D., Darnell, J., 2000. In: Freeman, W.H. (Ed.), Molecular Cell Biology, $4^{\text {th }}$ ed. New York.

Luan, L.Y., Zhang, Z.W., Xi, Z.M., Huo, S.S., Ma, L.N., 2014. Comparing the effects of exogenous abscisic acid on the phenolic composition of Yan 73 and Cabernet Sauvignon (Vitis vinifera L.) wines. Eur. Food Res. Technol. 239 (2), 203-213. https:// doi.org/10.1007/s00217-014-2206-z.

Mcguire, R.G., 1992. Reporting of objective color measurements. HortScience 27 (12) 1254-1255.

Olivares, D., Contreras, C., Muñoz, V., Rivera, S., González-Agüero, M., Retamales, J., Defilippi, B.G., 2017. Relationship among color development, anthocyanin and pigment-related gene expression in 'Crimson Seedless' grapes treated with abscisic acid and sucrose. Plant Physiol. Biochem. 115, 286-297. https://doi.org/10.1016/j. plaphy.2017.04.007.

Owen, S.J., Lafond, M.D., Bowen, P., Bogdanoff, C., Usher, K., Abrams, S.R., 2009 Profiles of abscisic acid and its catabolites in developing Merlot grape (Vitis vinifera) berries. Am. J. Enol. Vitic. 60, 277-284.

Peppi, M.C., Fidelibus, M.W., Dokoozlian, N., 2006. Abscisic acid application timing and concentration affect firmness, pigmentation and color of 'Flame Seedless' grapes. HortScience 41, 1440-1445.

Peppi, M.C., Fidelibus, M.W., Dokoozlian, N., 2007a. Application timing and concentration of abscisic acid affect the quality of 'Redglobe' grapes. J. Hort. Sci. Biotech. 82 (2), 304-310. https://doi.org/10.1080/14620316.2007.11512233.

Peppi, M.C., Fidelibus, M.W., Dokoozlian, N., 2008a. Timing and concentration of abscisic acid applications affect the quality of 'Crimson Seedless' grapes. Int. J. Fruit Sci. 7 (4), 71-83. https://doi.org/10.1080/15538360802003324.

Peppi, M.C., Walker, M.A., Fidelibus, M.W., 2008b. Application of abscisic acid rapidly upregulated UFGT gene expression and improved color of grape berries. Vitis 47 (1), $11-14$.

Ricce, W.S., Caramori, P.H., Roberto, S.R., 2013. Potencial climático para a produção de uvas em sistema de dupla poda anual no estado do Paraná. Bragantia 72 (4), 408-415. https://doi.org/10.1590/brag.2013.042.

Roberto, S.R., Assis, A.M., Yamamoto, L.Y., Miotto, L.C.V., Sato, A.J., Koyama, R., Genta, W., 2012. Application timing and concentration of abscisic acid improve color of 'Benitaka' table grape. Sci. Hort. 142, 44-48. https://doi.org/10.1016/j.scienta. 2012.04.028.

Roberto, S.R., De Assis, A.M., Yamamoto, L.Y., Miotto, L.C.V., Koyama, R., Sato, A.J., Borges, R.S., 2013. Ethephon use and application timing of abscisic acid for improving color of 'Rubi' table grape. Pesq. Agropec. Bras. 48 (7), 797-800. https://doi. org/10.1590/S0100-204X2013000700013.

Robinson, J., 2006. The Oxford Companion to Wine, $3^{\text {rd }}$ ed. Oxford University Press, New York. https://doi.org/10.1093/acref/9780198609902.001.0001.

Sandhu, A.K., Gray, D.J., Lu, J., Gu, L., 2011. Effects of exogenous abscisic acid on antioxidant capacities, anthocyanins and flavonol contents of muscadine grape (Vitis rotundifolia) skins. Food Chem. 126, 982-988. https://doi.org/10.1016/j.foodchem. 2010.11.105.

Taiz, L., Zeiger, E., 2003. Plant Physiology, 3rd ed. Oxford University press, New York https://dx.doi.org/10.1093\%2Faob\%2Fmcg079. 
Tecchio, M.A., Neto, F.J.D., Junior, A.P., Da Silva, M.J.R., Roberto, S.R., Smarsi, R.C., 2017. Improvement of color and increase in anthocyanin content of 'Niagara Rosada' grapes with application of abscisic acid. Afr. J. Biotechnol. 16 (25), 1400-1403. https://doi.org/10.5897/AJB2017.16073.

Xu, F., Luan, L.Y., Zhang, Z.W., Huo, S.S., Gao, X., Fang, Y.L., Xi, Z.M., 2014. Phenolic profiles and antioxidant properties of young wines made from Yan73 (Vitis vinifera L.) and Cabernet Sauvignon (Vitis vinifera L.) grapes treated by 24-epibrassinolide. Molecules 19, 10189-10207. https://doi.org/10.3390/molecules190710189.

Yamamoto, L.Y., Koyama, R., de Assis, A.M., Borges, W.F.S., de Oliveira, I.R., Roberto, S.R., 2015. Color of berry and juice of 'Isabel' grape treated with abscisic acid in different ripening stages. Pesq. Agropec. Bras. 50 (12), 1160-1167. https://doi.org/ 10.1590/S0100-204X2015001200005.

Zamboni, A., Carli, M.D., Guzzo, F., Stocchero, M., Zenoni, S., Ferrarini, A., Tononi, P., Toffali, K., Desiderio, A., Lilley, K.S., Pé, M.E., Benvenuto, E., Deledonne, M., Zezzotti, M., 2010. Identification of putative stage-specific grapevine berry biomarkers and omics data integration into networks. Plant Physiol. 154, 1439-1459. https://doi.org/10.1104/pp.110.160275.

Zhu, L., Zhang, Y., Zhang, W., Lu, J., 2016. Effects of exogenous abscisic acid on phenolic characteristics of red Vitis vinifera grapes and wines. Food Sci. Biotech. 25 (2), 361-370. https://doi.org/10.1007/s10068-016-0051-5. 